\title{
Purification and characterization of a specific late-larval esterase from two species of the Drosophila repleta group: contributions to understand its evolution
}

Vanessa F Lopes ${ }^{1}$, Hamilton Cabral ${ }^{2}$, Luciana PB Machado ${ }^{1}$ and Rogério P Mateus ${ }^{1 *}$

\begin{abstract}
Background: After duplication, one copy of an original gene can become redundant and decay toward a pseudogene status or functionally diverge. Here, we performed the purification and biochemical characterization of EST-4 (a late larval $\beta$-esterase) from two Drosophila repleta group species, Drosophila mulleri and Drosophila arizonae, in order to establish comparative parameters between these enzymes in these species and to contribute to better understand their evolution.

Results: In D. mulleri, EST-4 had an optimal activity in temperatures ranging from $40^{\circ}$ to $45^{\circ} \mathrm{C}$ and at $\mathrm{pH} 7.5$, maintaining stability in alkaline $\mathrm{pH}$ (8.0 to 10.0). It was classified as serine esterase as its activity was inhibited by PMSF. No ion negatively modulated EST-4 activity, and iron had the most positive modulating effect. In D. arizonae, it showed similar optimum temperature $\left(40^{\circ} \mathrm{C}\right), \mathrm{pH}(8.0)$, and was also classified as a serine esterase, but the enzymatic stability was maintained in an acidic $\mathrm{pH}$ (5.5 to 6.5). $\mathrm{Fe}^{+2}$ had the opposite effect found in D. mulleri, that is, negative modulation. $\mathrm{Al}^{+3}$ almost totally inhibited the EST-4 activity, and $\mathrm{Na}^{+}$and $\mathrm{Cu}^{+2}$ had a positive modulation effect. Kinetic studies, using $\rho$-nitrophenyl acetate as substrate, showed that EST-4 from D. mulleri had higher affinity, while in $D$. arizonae, it showed higher $V_{\max }$ and catalytic efficiency in optimal reaction conditions.

Conclusions: EST-4 from D. mulleri and D. arizonae are very closely related and still maintain several similar features; however, they show some degree of differentiation. Considering that EST-4 from D. mulleri has more conspicuous gel mobility difference among all EST-4 studied so far and a lower catalytic efficiency was observed here, we proposed that after duplication, this new copy of the original gene became redundant and started to decay toward a pseudogene status in this species, which probably is not occurring in D. arizonae.
\end{abstract}

Keywords: $\beta$-esterase; EST-4; D. mulleri; D. arizonae; Evolutionary biochemistry

\section{Background}

Several Drosophila species hold a class of $\beta$-esterase isoenzymes that have been reported to be encoded by a cluster of genes that are products of gene duplications (Zouros et al. 1982; Collet et al. 1990; East et al. 1990; Brady and Richmond 1992; Karotam et al. 1993; Oakeshott et al. 1999; Balakirev et al. 2005; Robin et al. 2009). These

\footnotetext{
*Correspondence: rogeriopmateus@gmail.com

'Laboratório de Genética e Evolução, Departamento de Ciências Biológicas, Universidade Estadual do Centro-Oeste (UNICENTRO), Campus CEDETEG, R. Simeão Camargo Varela de Sá, 03-Vila Carli, Guarapuava, Paraná 85040-080, Brazil

Full list of author information is available at the end of the article
}

enzymes have been studied regarding their biochemistry and genetic and evolutionary aspects, including some differences in enzymatic and biochemical properties (Zouros and van Delden 1982; Pen et al. 1984, 1986a, 1990; Korochkin et al. 1990; Brady and Richmond 1990; Richmond et al. 1990; Mateus et al. 2009, 2011), amino acid (Pen et al. 1986b, Pen et al. 1990) and gene sequencing (Balakirev et al. 2003; Robin et al. 2009), and gene localization in the chromosome (Gomes and Hasson 2003). In general, with some exceptions, two enzymes are detected in most species that hold this gene cluster, one expressed during all insect's life cycle and present mostly 
in the hemolymph, and other expressed in the late larvae and early pupae in the integument.

The more intensively $\beta$-esterase genes studied are Est6 and Est7 of Drosophila melanogaster subgroup (Oakeshott et al. 1995, 1999; Balakirev et al. 2006). They are tightly linked, and Est6 has acquired a novel function in this set of species (Oakeshott et al. 2000). In D. melanogaster, it is highly expressed in the sperm ejaculatory duct of the adult male instead of in the hemolymph, and the enzyme is transferred to the female during mating and modifies her subsequent egg-laying and remating behaviors (Meikle et al. 1990; Richmond et al. 1990; Saad et al. 1994). Est7 is predominantly expressed in the integumental tissue of late larvae and early pupae (Dumancic et al. 1997), and its function there still remains unknown.

In other species of the genus, the $\beta$-esterase gene cluster seems to be more complex in composition and function. In Drosophila pseudoobscura (obscura group, also D. melanogaster's subgenus Sophophora), three in tandem genes are found, and they show evidences of gene conversion or reciprocal recombination (Brady and Richmond 1992; King 1998). One of these three encodes the major adult hemolymph $\beta$-esterase (as D. melanogaster's Est6 above), but no function was detected for the other two genes (Brady and Richmond 1990; Tamarina et al. 1997). In Drosophila virilis (virilis group) and several cactophilic species (repleta group) of the subgenus Drosophila, the basic adult hemolymph and preadult integument $\beta$-esterases have been detected, and at least one and at most three $\beta$-esterases are present in the male ejaculatory bulb (Oakeshott et al. 1990, 1993). In Drosophila mojavensis, Robin et al. (2009) identified six paralog genes belonging to the $\beta$-esterase cluster and annotated, based on amino acid (Pen et al. 1986b) and gene sequence comparisons, that the isoenzymes, named EST-4 and EST-5 (Zouros et al. 1982), are probably the products of Est2c and Est2a genes, respectively. These enzymes have the same substrate preference for $\beta$-naphtyl esters (Zouros and van Delden 1982; Pen et al. 1984; Mateus et al. 2011), but as expected by default, they are highly differentiated about their temporal and tissue expression patterns. EST-4 is found only during the late larval stage and manly in the larvae cuticle, and EST-5 is present during throughout the insect's life cycle and predominantly in the hemolymph and fat body (Zouros et al. 1982; Pen et al. 1984). Drosophila buzzatii, a South American cactophilic species, also has very closely linked loci in chromosome 2 encoding esterase isozymes with the typical hemolymph and late larval/ early pupal cuticle expression profiles (East et al. 1990; Gomes and Hasson 2003).

In a more specific analysis in the repleta group, Zouros et al. (1982) detected EST-5 activity in all the 13 species they analyzed, but apparently, this was not true for EST-4. The activity of $\beta$-esterase in the larval carcass varied considerably among the species. It was abundant in most species, but it was barely detected in three (Drosophila aldrichi, D. repleta, and Drosophila peninsularis) and totally missing in other three (Drosophila tira, Drosophila hydei, and Drosophila eohydei). Mateus et al. (2011) studied six species of the same group of species and detected EST-4 and EST-5 activity in all the species: D. mojavensis cluster species (D. mojavensis, D. arizonae, and Drosophila navojoa) showed fainter bands than D. mulleri cluster species (D. mulleri, D. aldrichi, and Drosophila wheeleri).

A number of other results have shown that EST-4 and EST-5 are closely related, but with differences other than those already presented above. They have similar isoelectric points (between 6.0 and 7.0; Mateus et al. 2011), exhibit $82 \%$ identity in N-terminals of amino acid sequences (Pen et al. 1986b), and form an interloci heterodimer (Zouros et al. 1982; Mateus et al. 2011). However, they have different molar masses (Pen et al. 1984, 1986b; Mateus et al. 2009, 2011) and exhibit differential inhibition profiles, with EST-4 being inhibited by phenylmethanesulfonyl fluoride (PMSF) and not affected by malathion, and EST-5 being inhibited by malathion and not affected by PMSF (Mateus et al. 2011).

After duplication, a new copy of an original gene can take two possible pathways. It can become redundant and decay toward a pseudogene status or it functionally diverges. Gene duplication followed by functional divergence has been long considered the primary mechanism of molecular evolution (Lewis 1951; Ohno 1970). Balakirev and Ayala (1996) have detected high frequencies of null alleles (more than 60\%) for Est7 gene, which encodes the integumental tissue of late larvae and early pupae enzyme in $D$. melanogaster. The two explanations above have been suggested for this result. Balakirev and Ayala (2003) and Balakirev et al. (2006) proposed that the EST-7 protein has become redundant, and the gene is decaying toward a pseudogene status. Alternatively, Balakirev and Ayala (2004) suggested that the Est7 gene maintains a function that is not disabled by the stop codons or frame-shifting mutations detected.

According to Lima-Catelani et al. (2004), differences in esterase synthesis during the insect life cycle are probably due to differences in the regulatory mechanisms acting accordingly with metabolic function requirements of a variable number of processes in which esterases are involved during development. On the other hand, Robin et al. (2009) detected contrasting examples of the types and stages of loss of gene function for $\beta$-esterases as they inferred missing orthologs, pseudogenes, and null alleles, and a minimum of nine gene gain-loss events in the 12 species genome analyzed. They speculated that 
their results are probably related to fluctuation in the requirements for the functions of these genes over evolutionary time, possibly in response to changes in environmental niches. However, the reproductive functions of some $\beta$-esterases suggest that the copy number could have been changed by sexual competition or conflict.

Thus, this work aimed to investigate differences and compare several biochemical and enzymatic properties of EST-4 in two Drosophila species from the repleta group, $D$. mulleri and $D$. arizonae, in order to contribute to better understand the differentiation and evolution of this enzyme. Preliminary characterization of this enzyme showed, in D. mulleri, that it has the most different electrophoretic pattern from all other species analyzed so far, aside from some other distinct enzymatic features such as having the highest isoelectric point and molecular weight (Mateus et al. 2011). According to Harms and Thornton (2013), an integration of evolution with biochemistry is indispensable to achieve a more complete understanding of why biological molecules have the properties that they do. Our results are in agreement to previous achievements, and the lower $V_{\max }$ and catalytic efficiency detected for $D$. mulleri lead us to propose that after duplication, this copy of the original gene became redundant and started to decay toward a pseudogene status in this species, which probably is not occurring in D. arizonae.

\section{Methods}

\section{Species}

Multifemale lineages of the two species, D. mulleri and D. arizonae, were obtained from Prof. Dr. Carlos Roberto Ceron (Department of Chemistry and Environmental Sciences, IBILCE/UNESP, São José do Rio Preto, Brazil). They were maintained as mass cultures in $250-\mathrm{mL}$ culture vials with standard banana agar medium in constant temperature of $25^{\circ} \mathrm{C} \pm 1^{\circ} \mathrm{C}$ and 12-h photoperiod.

\section{EST-4 purification}

\section{Sample preparation}

Late-third instar larvae of both species were obtained directly from the maintenance vials, and in order to maximize sample attainment, intraspecific crosses were performed. Virgin males and females were separated, and after 7 days, ten vials containing standard culture medium were prepared. Five couples were crossed for 21 days, transferring them into new vials every 7 days. All vials were daily checked for tracking larval development, separating those larvae that were at the desired stage.

The larvae collected were immediately frozen in liquid nitrogen and stored at $-80^{\circ} \mathrm{C}$. The enzyme extracts were obtained by macerating 400 late-third instar larvae in $0.1 \mathrm{M}$ phosphate buffer at $\mathrm{pH} 6.2$ and centrifuging at $10,000 \times \mathrm{g}$ in $4^{\circ} \mathrm{C}$ for $10 \mathrm{~min}$. A sample of each supernatant was electrophoresed in $10 \%$ non-denaturing polyacrylamide gel, as described by Mateus et al. (2011) and adapted in 'Molar mass exclusion and ion exchange chromatographies' section below, in order to detect the presence of EST-4. An adult was used as a comparative sample.

\section{Molar mass exclusion and ion exchange chromatographies}

The purification in gel filtration through molecular mass exclusion chromatography (MMEC) was performed using Sephadex G-75 resin (GE Healthcare, São Paulo, Brazil), which was packed into a $4 \times 100-\mathrm{cm}$ (diameter $\times$ height) column. Fractionation was performed at $4^{\circ} \mathrm{C}$ using $0.1 \mathrm{M}$ phosphate buffer at $\mathrm{pH} 6.2$ and a $0.6-\mathrm{mL} /$ min flow. Fractions of $5 \mathrm{~mL}$ were collected and individually analyzed for larval esterase activity in polyacrylamide gel electrophoresis (PAGE), mixing $20 \mu \mathrm{L}$ of the fraction with $5 \mu \mathrm{L}$ sample buffer $(25 \%$ Tris- $\mathrm{HCl}$ buffer $(0.05 \mathrm{M})$ $\mathrm{pH}$ 6.8, 20\% glycerol, and 0.02\% bromophenol blue). The electrophoresis was performed in 10\% PAGE as described by Mateus et al. (2011) at constant voltage of $110 \mathrm{~V}$ in room temperature. To test the substrate specificity, the gels were soaked with usual $\alpha$ - and $\beta$-naphthyl acetate solution (Mateus et al. 2011), and their products were stained for $2 \mathrm{~h}$ using Fast Blue RR salt (Sigma-Aldrich, São Paulo, Brazil).

The fractions that showed EST-4 activity were joined and dialyzed in $20 \mathrm{mMN} N$-[tris(hydroxymethyl)methyl]3-aminopropanesulfonic acid (TAPS) buffer at $\mathrm{pH} 8.5$ for $24 \mathrm{~h}$ at $4^{\circ} \mathrm{C}$ and with three exchanges. The dialyzed material was submitted to ion exchange chromatography (IEC) in a Q-Sepharose resin (GE Healthcare, São Paulo, Brazil) with the same buffer above. The sample was washed with elution buffer (20 mM TAPS buffer of $\mathrm{pH} 8.5$ without $\mathrm{NaCl}$ ) to remove unbound material. The elution of proteins was initiated with linear salt gradient ranging from 0 to $2 \mathrm{M} \mathrm{NaCl}$ in the same buffer. Fractionation was performed at $4{ }^{\circ} \mathrm{C}$ with a $1.0-\mathrm{mL} / \mathrm{min}$ flow, and 5-mL fractions were collected.

After each chromatography, EST-4 purity was certified through denaturing gel electrophoresis (10\% sodium dodecyl sulfate (SDS)-PAGE) according to Laemmli (1970). The samples $(20 \mu \mathrm{L})$ were mixed with $10 \mu \mathrm{L}$ sample buffer (25\% Tris-HCl buffer (0.05 M), pH 6.8, 3.1\% DTT $(w / v), 0.02 \%$ Bromophenol Blue, 20\% glycerol, and $4 \%$ SDS $(w / v))$. This mixture was boiled for $5 \mathrm{~min}$ at $96^{\circ} \mathrm{C}$, and after electrophoresis, the gel was stained with silver nitrate (See and Jackowski 1989).

\section{EST-4 activity test}

The esterase activity was measured using the protocol described by Immanuel et al. (2010) with some modifications: $25 \mu \mathrm{L}$ of enzyme extract, $25 \mu \mathrm{L}$ of $0.05 \mathrm{M}$ 4-(2-hydroxyethyl)piperazine-1-ethanesulfonic acid (HEPES) buffers 
(pH 7.0 for D. mulleri and $\mathrm{pH} 7.5$ for $D$. arizonae), and $450 \mu \mathrm{L}$ of $\rho$-nitrophenyl as substrate. The unit of the esterase activity used was the equivalent to one micromole of $\rho$-nitrophenyl released per unit of time (minute) under standard test conditions, that is, the amount of enzyme required to cause an increase of $0.001 \mathrm{~A}_{280 \mathrm{~nm}}$. All assays were performed in triplicate. The calculation of esterasic unit was realized according to Semionato (2006), in which the unit of enzyme is given by the following formula:

$$
U=\frac{\mathrm{Abs} \times V_{\mathrm{R}} \times 1,000}{e \times t \times V_{\mathrm{E}}}
$$

where, Abs means absorbance at $410 \mathrm{~nm}, V_{\mathrm{R}}$ is the volume of reaction which is $500 \mu \mathrm{L}, e$ is the molar extinction coefficient of $\rho$-nitrophenyl which is $18.5 \mu \mathrm{mol} \mathrm{mL} \mathrm{m}^{-1} \mathrm{~cm}^{-1}$, $t$ is time in minutes, and $V_{\mathrm{E}}$ is the volume of enzyme which is $25 \mu \mathrm{L}$.

\section{Protein quantification}

The esterase quantification was determined according to the method described by Bradford (1976), using standard curve constructed with bovine serum albumin (BSA).

\section{Biochemical characterization of EST-4 pH effect on the EST-4 activity and stability}

Optimum $\mathrm{pH}$ and $\mathrm{pH}$ stability characterization of both enzymes were carried out with $\mathrm{pH}$ ranging from 4.5 to 10.5, varying $0.5 \mathrm{U}$. The following buffers were used: acetate ( $\mathrm{pH} 4.5$ and 5.0), 2-[N-morpholino] ethanesulfonic acid (MES; $\mathrm{pH} 5.5,6.0$, and 6.5), HEPES (pH 7.0, 7.5, and 8.0); N,N-bis(2-hydroxyethyl)glycine (BICINE; $\mathrm{pH} 8.5$ and 9.0), and 3-(cyclohexylamino)-1-propanesulfonic acid (CAPS; $\mathrm{pH} 9.5,10.0$, and 10.5). All the buffers were prepared with $0.05 \mathrm{M}$ of concentration. The reaction mixes contained $25 \mu \mathrm{L}$ of purified enzyme, $25 \mu \mathrm{L}$ of buffer (ranging from $\mathrm{pH} 4.5$ up to 10.5, described above), and $450 \mu \mathrm{L}$ of $\rho$-nitrophenyl acetate substrate. Thus, thirteen different mixes were set up, each one with different final $\mathrm{pH}$, and they were incubated at $40^{\circ} \mathrm{C}$ for $30 \mathrm{~min}$. After this period, the esterase activity was measured accordingly to the method described above ('EST-4 activity test' section).

The $\mathrm{pH}$ stability was determined by incubating the enzymes $(25 \mu \mathrm{L})$ for $1 \mathrm{~h}$ at $25^{\circ} \mathrm{C}$ at different $\mathrm{pH}$ values (using the buffers described above), subsequently adding $450 \mu \mathrm{L}$ of $\rho$-nitrophenyl acetate substrate, $13 \mu \mathrm{L}$ of optimum $\mathrm{pH}$ buffer ( $\mathrm{pH} 6.5$ to D. mulleri and $\mathrm{pH} 7.5$ to $D$. arizonae), and determining the activity as described above at $40^{\circ} \mathrm{C}$ for $30 \mathrm{~min}$.

\section{Temperature effect on the EST-4 activity}

The influence of temperature on the activity of EST-4 was performed in optimal $\mathrm{pH}$ (7.0 for D. mulleri and 7.5 for $D$. arizonae) and temperature of $25^{\circ} \mathrm{C}$ to $55^{\circ} \mathrm{C}$, with variations of $5^{\circ} \mathrm{C}$. The pure enzymes $(25 \mu \mathrm{L})$ were mixed with $25 \mu \mathrm{L}$ of optimum $\mathrm{pH}$ buffer and $450 \mu \mathrm{L}$ of $\rho$-nitrophenyl acetate substrate, as described in the 'EST-4 activity test' section. The enzyme activities were evaluated proceeding incubation for $30 \mathrm{~min}$ in the respective temperatures.

\section{Chemical effect on the EST-4 activity}

The determination of active site constitution of both enzymes was performed according to the protocol described by Dunn (1989) with modifications. The following reagents were used in a final concentration of $5 \mathrm{mM}$ : PMSF, EDTA (ethylenediamine tetraacetic acid), and pepstatin.

The pure enzymes $(25 \mu \mathrm{L})$ were premixed with $2.5 \mu \mathrm{L}$ of each inhibitor, incubated at $40^{\circ} \mathrm{C}$ for $5 \mathrm{~min}$, and after that period, $22.5 \mu \mathrm{L}$ of optimum $\mathrm{pH}$ buffer and $450 \mu \mathrm{L}$ of $\rho$-nitrophenyl acetate substrate were added. The enzyme activities were checked by incubating them for $30 \mathrm{~min}$ at $40^{\circ} \mathrm{C}$. The control tube was made with addition of $25 \mu \mathrm{L}$ pure enzyme, $450 \mu \mathrm{L}$ of $\rho$-nitrophenyl acetate, and $25 \mu \mathrm{L}$ of optimum $\mathrm{pH}$ buffer.

The effects of metal ions on the esterase activities were investigated by adding monovalent $\left(\mathrm{Li}^{+}, \mathrm{Na}^{+}\right.$, and $\left.\mathrm{K}^{+}\right)$ and divalent ions $\left(\mathrm{Ba}^{2+}, \mathrm{Ca}^{2+}, \mathrm{Mg}^{2+}, \mathrm{Mn}^{2+}, \mathrm{Fe}^{2+}, \mathrm{Ni}^{2+}\right.$, $\mathrm{Cu}^{2+}$, and $\mathrm{Zn}^{2+}$ ) to a final $10 \mathrm{mM}$ concentration. The pure enzymes $(25 \mu \mathrm{L})$ were preincubated with each ion $(2.5 \mu \mathrm{L})$ at $40^{\circ} \mathrm{C}$ for $5 \mathrm{~min}$. Subsequently, the enzyme activities were evaluated at $40^{\circ} \mathrm{C}$ for $30 \mathrm{~min}$ and added with $450 \mu \mathrm{L}$ of $\rho$-nitrophenyl acetate substrate and $22.5 \mu \mathrm{L}$ of optimum $\mathrm{pH}$ buffer. The control tube was made with the addition of $25 \mu \mathrm{L}$ pure enzyme, $450 \mu \mathrm{L}$ of $\rho$-nitrophenyl acetate, and $25 \mu \mathrm{L}$ of optimum $\mathrm{pH}$ buffer.

\section{EST-4 enzymatic kinetics}

The enzyme kinetics was obtained for both EST-4 by adding increasing concentrations of $\rho$-nitrophenyl acetate substrate, from 0.1 to $1.0 \mathrm{mM}$. The experiments were performed in the optimum $\mathrm{pH}$ and at $40^{\circ} \mathrm{C}$, and the results were read in a spectrophotometer with 410-nm absorbance.

The $K_{\mathrm{m}}$ and $V_{\max }$ kinetic values were obtained using Michaelis-Menten equation calculated by non-linear regression of data from hydrolysis of the substrate using the software GraFit version 5.0 (Erithacus Software Ltd., Surrey, UK). $K_{\mathrm{m}}, K_{\mathrm{cat}}$, and $K_{\text {cat }} / K_{\mathrm{m}}$ were evaluated by determining the enzyme activities against $\rho$-nitrophenyl acetate substrate in ideal conditions.

\section{Results and discussion}

Purification of EST-4 from D. mulleri and D. arizonae Chromatography

After gel filtration through MMEC, two protein peaks with esterase activity were detected in D. mulleri 

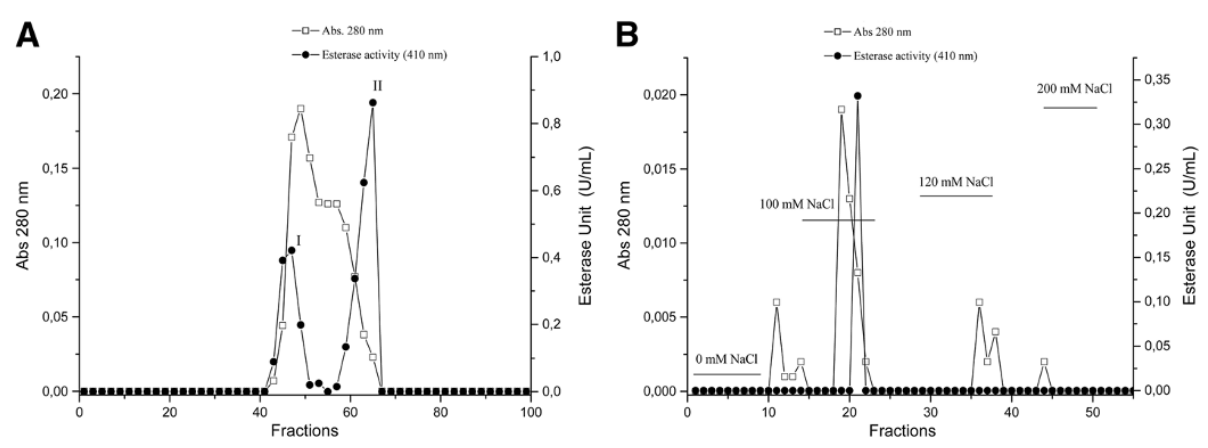

Figure 1 Elution profiles for Drosophila mulleri. MMEC-Sephadex G-75 (A) and IEC-Sepharose Q (B).

(Figure 1A) and D. arizonae (Figure 2A). The elution profile of the fractions was analyzed in 10\% PAGE, using a larva as control (Figure 3). According to Zouros et al. (1982), Pen et al. (1984), and Mateus et al. (2011), EST-4 shows preference for $\beta$-naftil acetate, therefore stains in pink, which was observed in the gels. EST-4 was found in peak II in D. mulleri and peak I in D. arizonae. Fractions that showed EST-4 activity in the gel were pooled and submitted to SDS-PAGE to certify the degree of enzyme purification. The results showed partial purification of EST-4 (results not shown). The pooled fractions were dialyzed, concentrated, and submitted to IEC to enhance enzyme purity. After this second chromatography, the elution profile of the fractions was again analyzed in 10\% PAGE using a larva as control (results not shown). EST-4 from D. mulleri was detected in the protein peak of $100 \mathrm{mM}$ of $\mathrm{NaCl}$ (Figure 1B) and from D. arizonae in the protein peak of $200 \mathrm{mM}$ of salt (Figure 2B). The certification of EST-4 purity in the fractions was confirmed by SDS-PAGE (Figure 4). Those containing purified EST-4 were pooled and concentrated for its further biochemical characterization.

The molar mass of EST-4 was determined using protein molecular weight marker (low molecular weight SDS calibration kit for SDS electrophoresis, GE Healthcare) in the SDS-PAGE gel. As seen in Figure 4, the molar masses of the purified EST-4 (correspondent to the purified protein subunit (arrow)) of $D$. mulleri and D. arizonae are approximately $45 \mathrm{kDa}$. Pen et al. (1984) determined the molar mass of EST-4 of D. mojavensis also using denaturing gel electrophoresis (SDS-PAGE) and obtained values between 62 and $64 \mathrm{kDa}$ for its subunits. Similarly, the molar mass of 64 to $66 \mathrm{kDa}$ for the subunits of EST-5 of the same species was found by Pen et al. (1986a). As pointed out before, EST-4 and EST-5 are expressed by duplicated genes, Est $2 c$ and Est $2 a$, respectively, in these species. Mateus et al. (2011) and Pen et al. (1984) have determined the molar mass of the dimeric EST-4 protein as being between 83 and $95 \mathrm{kDa}$. Therefore, our results showed a more congruent data for the molar mass of the subunit, as it appears to have half the mass of the dimeric protein, and not the anomalous behavior previously found by Pen et al. (1984, 1986a).

The experimental purification data are summarized in Table 1. After the first step of the purification procedure, MMEC, the esterases from $D$. mulleri were purified 2.41 -fold, and $5.17 \%$ recovery was obtained. After the second step of purification, IEC, EST-4 was purified 3.37 -fold with a total of $3.61 \%$ recovery. $D$. arizonae showed better results, with a 1.67 -fold esterase purification and 52.2\% recovery after MMEC, and 3.14-fold
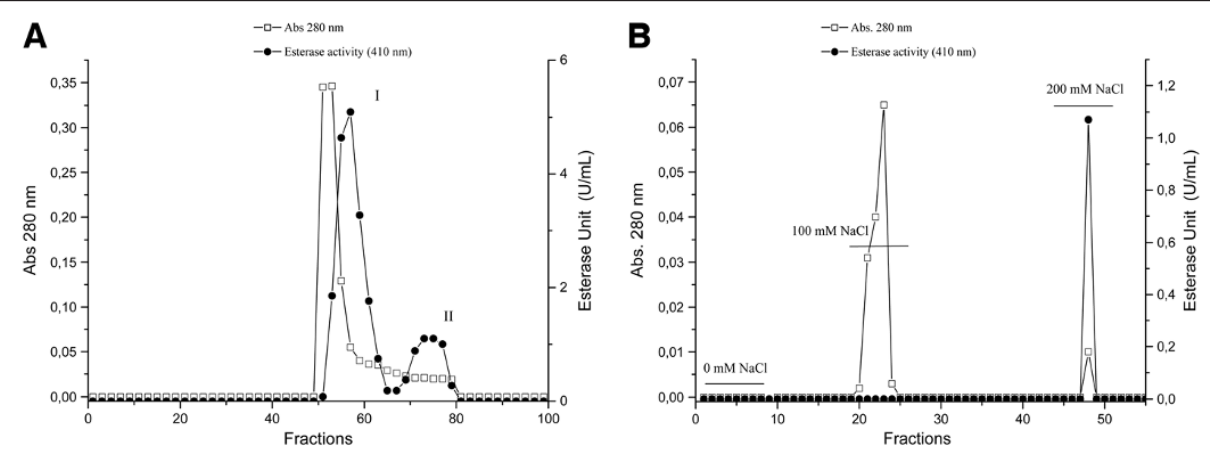

Figure 2 Elution profile for Drosophila arizonae. MMEC-Sephadex G-75 (A) and IEC-Sepharose Q (B). 


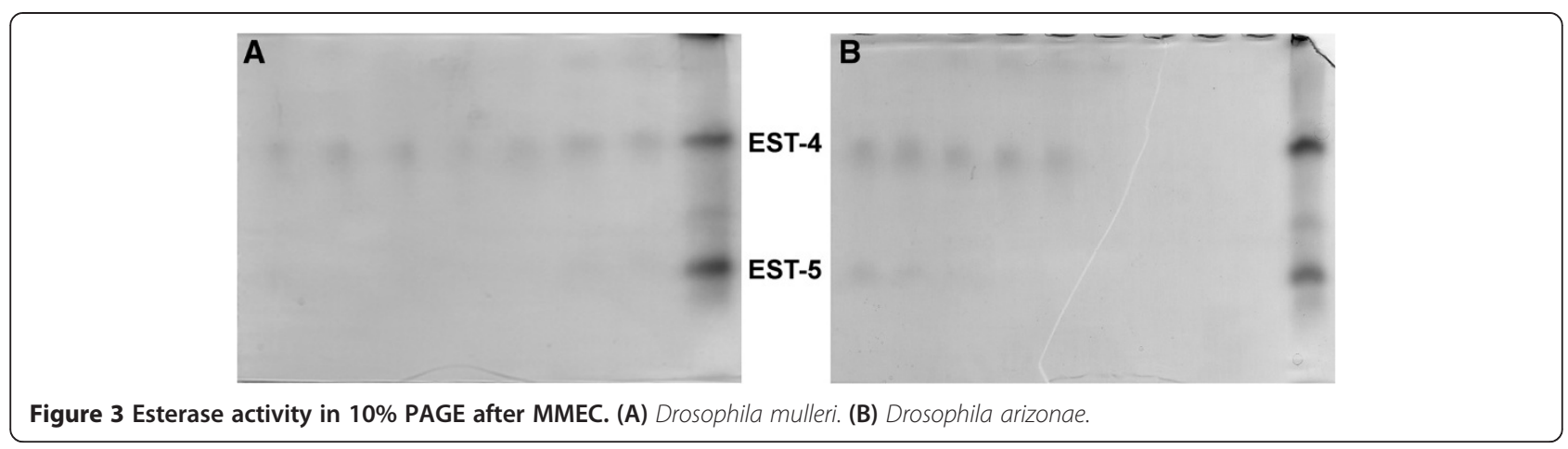

purification and $6.65 \%$ recovery after IEC. Therefore, EST-4 recovery after the purification process in $D$. arizonae was approximately twice higher than that in $D . m u l$ leri. Similar results were obtained in a study involving purification and characterization of EST-5 from D. pseudoobscura, also classified as $\beta$-esterase, by Narise and Hubby (1966) who obtained 3.0-fold purification and $2.4 \%$ recovery of this enzyme. However, other works obtained much higher recovery after esterase purification. Pen et al. (1984) obtained 820-fold purification and 27\% recovery of EST-4 activity from $D$. mojavensis. In other insects, Zera et al. (2002) purified and characterized the juvenile hormone esterase (JHE) from Gryllus assimilis, and after four steps of purification, they obtained more than 900-fold purification and 30\% enzyme activity recovery. These much higher purification results are probably related to the amount of initial sample obtained for protein extraction ( $1 \mathrm{~g}$ of larvae in the case of Pen et al. 1984) and/or differences in the purification procedures applied (seven steps in Pen et al. 1984, while four steps in Zera et al. 2002).

\section{Biochemical characterization of EST-4 \\ Effect of $\mathrm{pH}$ on the EST-4 activity and stability}

EST-4 of both species had similar activity profiles on different $\mathrm{pH}$ buffers. The optimum activities were detected in alkaline $\mathrm{pH}, 7.5$ for D. mulleri (Figure 5A) and 8.0 for $D$. arizonae (Figure $5 \mathrm{~B}$ ). These results showed that these enzymes have the best structural conformation state, and consequently better catalytic performance, almost at the same $\mathrm{pH}$. However, the enzyme activity profiles in the surrounding $\mathrm{pH}$ had differences. EST-4 of $D$. mulleri showed around $40 \%$ to $60 \%$ of its optimum activity in the $\mathrm{pH}$ levels of 7.0, 8.0, 8.5, and 9.0; result not observed for EST4 from $D$. arizonae, which displayed $40 \%$ to $60 \%$ of its activity only in the nearest optimum $\mathrm{pH}, 7.5$ and 8.5.

The enzyme stability tests also showed that EST-4 from both species had differences. EST-4 of D. mulleri had lower residual esterase activity in an acid $\mathrm{pH}$, maintaining approximately $80 \%$ of its activity in $\mathrm{pH}$ between 5.0 and 6.5 (Figure 6A). However, the higher the $\mathrm{pH}$, the higher the enzyme stability, and this enzyme had more stable activity in alkaline $\mathrm{pH}$ levels, especially between 8.0 and 10.0. For D. arizonae, EST-4 showed lower stability in alkaline $\mathrm{pH}$, retaining approximately $40 \%$ of its residual activity in the $\mathrm{pH}$ around 8.0 and 10.0, and it was more stable in acidic $\mathrm{pH}$, especially around $\mathrm{pH} 5.5$ and 7.0, where its activity was approximately $80 \%$ (Figure 6B).

Therefore, regarding $\mathrm{pH}$, both EST-4 had similar optimum $\mathrm{pH}$ curve but different $\mathrm{pH}$ stability. Thomazine (2007) studied two enzymatic variants of EST-5, called fast (EST-5 F) and slow (EST-5S), and found that these allozymes presented $\mathrm{pH}$ profiles similar to that described here, i.e., optimum activity in alkaline $\mathrm{pH}$ and lower activity in acid $\mathrm{pH}$. In a study of characterization of JHE in D. melanogaster, Campbell et al. (1992) found that below $\mathrm{pH}$ 6.0, considerable non-enzymic, acid hydrolysis of juvenile hormone $(\mathrm{JH})$ occurred. Over the $\mathrm{pH}$ range from 6.0 to 8.6 , the JHE activity almost doubled, increasing linearly with increasing $\mathrm{pH}$. No further change in activity was observed at $\mathrm{pH}$ 9.0. Therefore, they showed that JHE from D. melanogaster also had a tendency of better activity on alkaline environment.

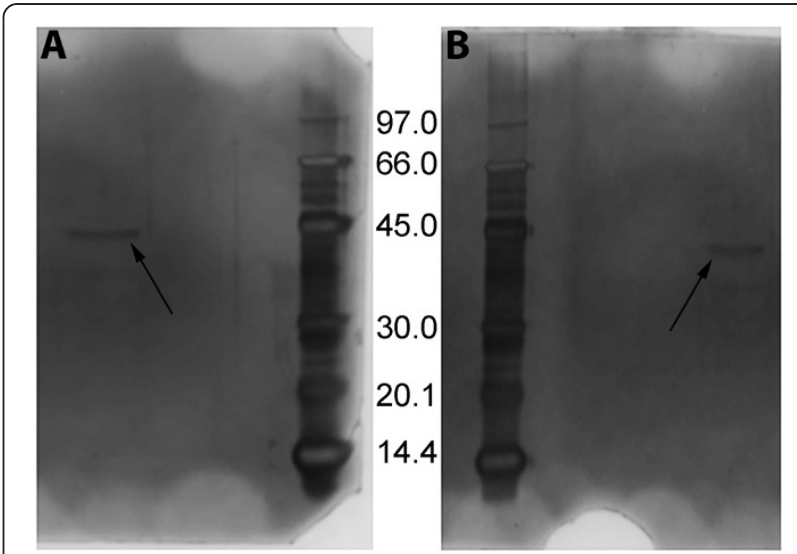

Figure 4 10\% SDS-PAGE of purified EST-4 (arrows) from $D$. mulleri (A) and $D$. arizonae (B). Molecular weights between gels in $\mathrm{kDa}\left(1 \times 10^{-3} \mathrm{Da}\right)$. 
Table 1 EST-4 purification features from Drosophila mulleri and Drosophila arizonae after MMEC and IEC

\begin{tabular}{|c|c|c|c|c|c|}
\hline Purification steps & Total protein $(\mathrm{mg})$ & Total activity (U) & Specific activity (U/mg) & Recovery (\%) & Purification (fold) \\
\hline \multicolumn{6}{|l|}{ D. mulleri } \\
\hline Crude extract & 0.1400 & 46.00 & 328.57 & 100.00 & 1.00 \\
\hline MMEC & 0.0030 & 2.38 & 793.33 & 5.17 & 2.41 \\
\hline IEC & 0.0015 & 1.66 & $1,106.66$ & 3.61 & 3.37 \\
\hline \multicolumn{6}{|l|}{ D. arizonae } \\
\hline Crude extract & 0.1700 & 241.35 & $1,419.70$ & 100.00 & 1.00 \\
\hline MMEC & 0.0530 & 126.00 & $2,377.36$ & 52.20 & 1.67 \\
\hline IEC & 0.0036 & 16.05 & $4,458.33$ & 6.65 & 3.14 \\
\hline
\end{tabular}

\section{Effect of temperature on the EST-4 activity}

EST-4 from D. mulleri showed optimum temperatures of $40^{\circ} \mathrm{C}$ and $45^{\circ} \mathrm{C}$ (Figure $7 \mathrm{~A}$ ). Its activity decreased to about half when incubated at temperatures $5^{\circ} \mathrm{C}$ below $\left(35^{\circ} \mathrm{C}\right)$ and above $\left(50^{\circ} \mathrm{C}\right)$ these optimum temperatures. Temperatures below $35^{\circ} \mathrm{C}$ and above $50^{\circ} \mathrm{C}$ completely eliminated the enzyme activity. For $D$. arizonae, the EST-4 optimum temperature was $40^{\circ} \mathrm{C}$ (Figure 7B), decreasing to less than $80 \%$ of its activity when treated in $35^{\circ} \mathrm{C}$, and to around $50 \%$ to $60 \%$ when treated in $45^{\circ} \mathrm{C}$ and $50^{\circ} \mathrm{C}$. Temperatures below $35^{\circ} \mathrm{C}$ and above $50^{\circ} \mathrm{C}$ strongly affected the enzyme, remaining less than $20 \%$ of its original activity.

These results provide evidence that both enzymes had similar optimum temperatures, with minor differences as EST-4 from D. mulleri operated better at higher temperatures $\left(45^{\circ} \mathrm{C}\right)$ when compared to $D$. arizonae. Thomazine (2007) found even higher optimum temperature in experiments with variants of EST-5 (slow and fast) of D. mulleri, which showed higher activity at $50^{\circ} \mathrm{C}$. However, when these variants were incubated for $10 \mathrm{~min}$ at $55^{\circ} \mathrm{C}$, no activity was detected for EST-5 F.

\section{Effect of chemicals on the EST-4 activity}

To classify the chemical nature of the catalytic site, i.e., the main residue composition in enzyme active site, the effect of the reagents was studied by incubating EST-4 in their presence. The essays showed that the largest reduction in esterase activity was caused by PMSF, approximately $85 \%$ for $D$. mulleri (Figure $8 \mathrm{~A}$ ) and $90 \%$ for $D$. arizonae (Figure $8 \mathrm{~B}$ ), suggesting that both belong to the class of serine esterases. According to Zhou et al. (1994), serine esterases catalyze the hydrolysis of esters and amides via covalent ester bound, which is formed between the substrate acyl portion and the serine residue of the enzyme active site.

These inhibition results corroborate the previously data of Mateus et al. (2011) who detected that the EST-4 of six species of the $D$. repleta group, including the two studied here, were all inhibited by PMSF. According to Dunn (1989), this type of inhibition probably occurs because this compound irreversibly binds to the hydroxyl side chain of the serine residue, impeding the enzymatic catalysis. This class of esterase is commonly found in insects (see Krejci et al. 1991, Anthony et al. 1995, Hinton and Hammock 2003, Coutinho-Abreu et al. 2007, Yu et al. 2009, and Li et al. 2010 as examples). However, in some insects, they were not detected. For example, in a study of biochemical identification and characterization of esterases in Tribolium castaneum, Gigliolli et al. (2011) observed that all enzymes were inhibited by eserine sulfate and/or malathion, and none by PMSF.
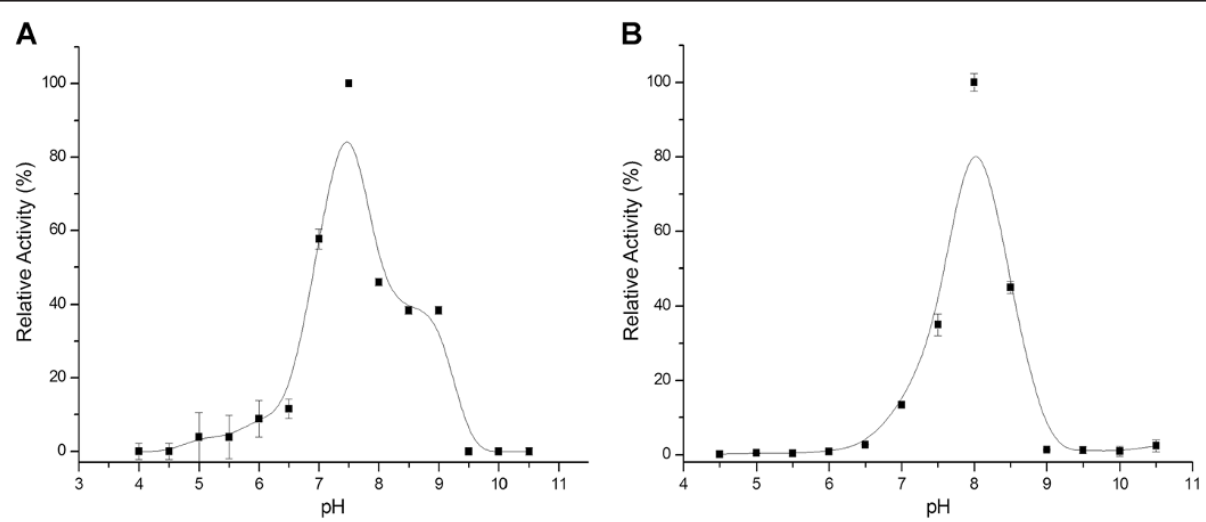

Figure 5 EST-4 activity in different pH levels. (A) D. mulleri. (B) D. arizonae. 

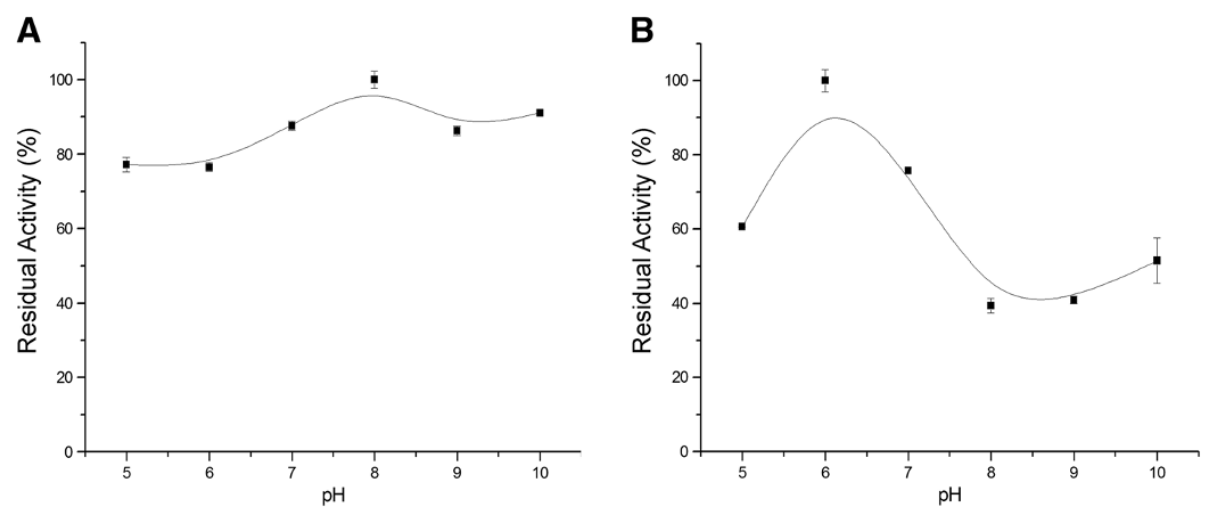

Figure 6 EST-4 stability in different pH levels. (A) D. mulleri. (B) D. arizonae.

Other two compounds also affected the EST-4 activity in our experiments. EDTA was responsible for more than $70 \%$ decrease in EST-4 activity in D. arizonae and about $35 \%$ decrease in the $D$. mulleri, suggesting that these esterases probably have their activity modulated positively in the presence of metal ions. In the presence of this compound, the ions were possibly chelated, resulting in the observed inhibition. Pepstatin was responsible for reducing approximately $20 \%$ of the enzymatic activity of EST-4 in both species. Serine enzymes commonly present a catalytic triad composed of serine, histidine, and aspartate residues, which indirectly interact, enhancing enzyme activity (Zhou et al. 1994). This inhibitor probably is connected to the aspartate residue causing the observed reduction in the EST- 4 activity.

Considering the result with EDTA, the effect of metal ions on the activity of EST-4 of both species was also tested. These chemicals can be determinants in the protein molecular organization and can influence its enzymatic activity and stability. In D. mulleri (Figure 9A), $\mathrm{Fe}^{+2}$ increased fivefold the EST-4 activity compared to the control. Knowing that ions can bind to amino acids and influence protein structural conformation, directly affecting the catalytic performance of the enzyme (Merheb-Dini et al. 2009), we were able to propose that $\mathrm{Fe}^{+2}$ bound to EST-4 of D. mulleri and improved the enzyme activity probably because it made the enzyme structure better organized. $\mathrm{Na}^{+}$and $\mathrm{Ba}^{+2}$ also showed a positive modulation effect, increasing around $50 \%$ of the EST-4 activity. These ions also probably linked to the enzyme, facilitating its catalytic function. $\mathrm{Co}^{+2}, \mathrm{Cu}^{+2}$, $\mathrm{Li}^{+}$, and $\mathrm{Ca}^{+2}$ did not affect the enzymatic activity of EST-4 in this species. All other ions $\left(\mathrm{Mg}^{+2}, \mathrm{~K}^{+}, \mathrm{Mn}^{+2}\right.$, $\mathrm{Zn}^{+2}$, and $\mathrm{Al}^{+3}$ ) promoted a small activating effect. It is noteworthy that none of the metal ions had negative modulating effect on this esterase activity.

In the case of $D$. arizonae, $\mathrm{Na}^{+}$and $\mathrm{Ba}^{+2}$, together with $\mathrm{Cu}^{+2}$ and $\mathrm{Co}^{+2}$, also activated more than $50 \%$ (around $60 \%$ ) of the EST-4 activity (Figure 9B). However, different from $D$. mulleri, several ions decreased the esterase activity, such as $\mathrm{Fe}^{+2}, \mathrm{Li}^{+}, \mathrm{Mg}^{+2}, \mathrm{Ca}^{+2}, \mathrm{~K}^{+}, \mathrm{Mn}^{+2}, \mathrm{Zn}^{+2}$, and $\mathrm{Al}^{+3}$. This last one inhibited nearly $100 \%$ of the enzyme activity, and in this case, it is possible that it bound to the enzyme, promoting negative modulatory effect and preventing it to perform its catalytic function. Negative modulation of serine protease activity in the
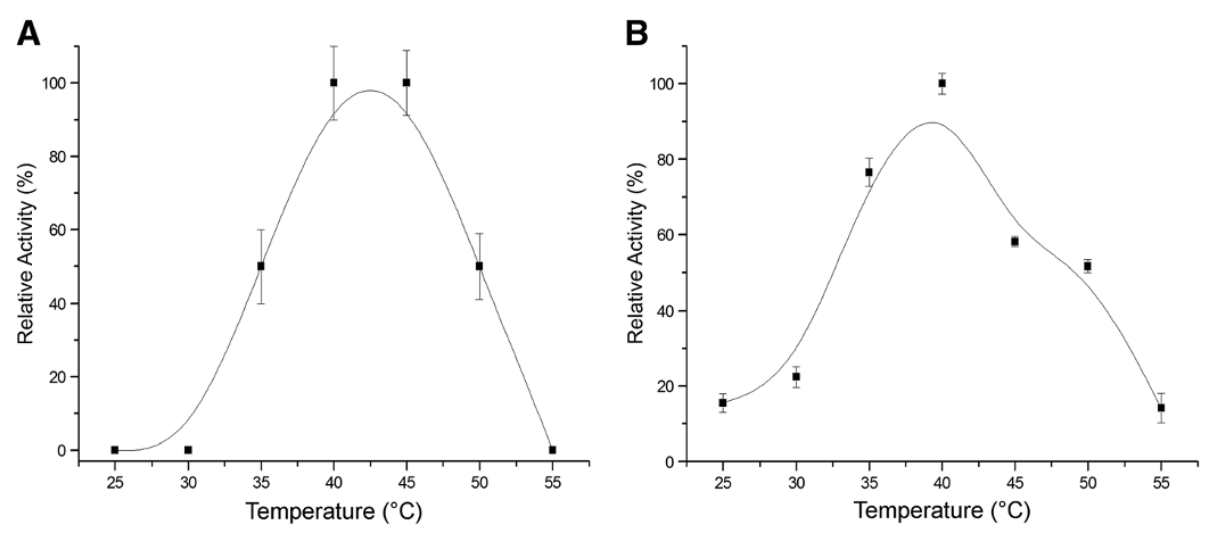

Figure 7 EST-4 activity in different temperatures. (A) D. mulleri. (B) D. arizonae. 

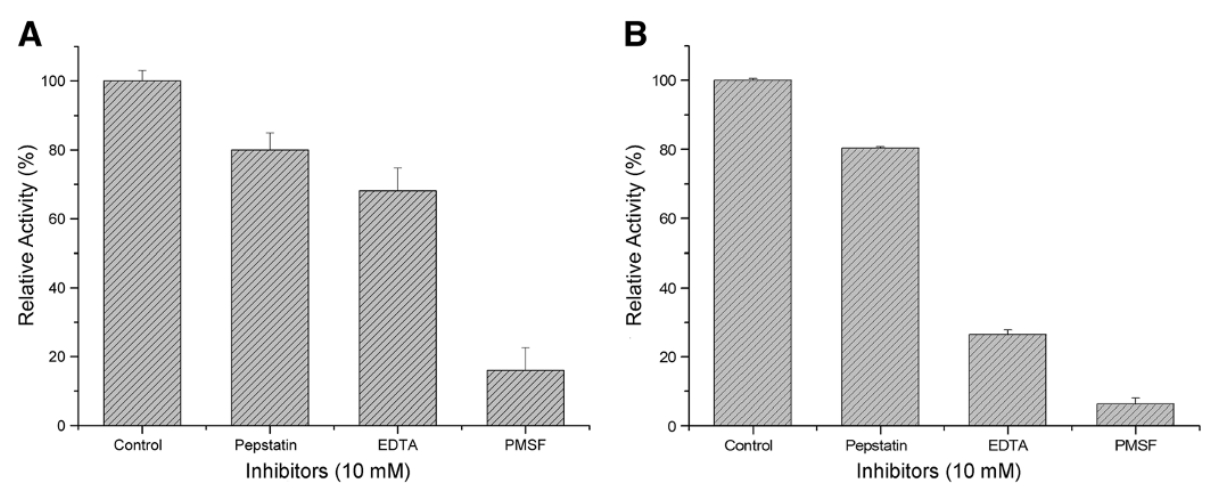

Figure 8 EST-4 activity in the presence of inhibitors. (A) D. mulleri. (B) D. arizonae.

presence of $\mathrm{Al}^{+3}$ was also observed by Silva (2011) in the fungus Aspergillus fumigatus Fresenius. They detected, among all ions tested, that the enzyme had its activity reduced about $80 \%$ only in the presence of this ion.

Therefore, the differences in the modulator effect of $\mathrm{Fe}^{+2}$ in both species are noteworthy. It was responsible for the activation of EST-4 in D. mulleri, and it had a negative modulatory effect in $D$. arizonae, decreasing approximately $40 \%$ of the esterase activity. Moreover, $\mathrm{Al}^{+3}$ showed an effect (positive or negative) over EST-4 of D. mulleri and was responsible for almost the complete inhibition of EST-4 in $D$ arizonae. Thus, it can be suggested that although paralog genes with similar temporal and tissue expressions encode these enzymes, they are biochemically distinct in their catalysis regarding the presence of ions.

\section{Kinetic parameters of EST-4}

Kinetic parameters are peculiar and intrinsic in each enzyme/substrate relationship, depending entirely on the enzyme specificity. Studies about kinetic parameters of esterases, especially in Drosophila and using $\rho$-nitrophenyl acetate, are scarce and poorly described in the literature. In a study of purification and characterization developed by
Zera et al. (2002), the JHE present in Gryllus assimilis hydrolyzed $\alpha$-naphthyl and $\rho$-nitrophenyl esters, and according to these authors, the JHE studied probably can hydrolyze any ester with long aliphatic chains. Campbell et al. (1998) purified and characterized the D. melanogaster JHE, and it only hydrolyzed the substrate $\alpha$-naphthyl acetate. In our case, both EST-4 depict the preference for $\beta$-naphthyl and were able to hydrolyze both $\alpha$-naphthyl and $\rho$-nitrophenyl esters, as the JHE of G. assimilis. Using $\rho$-nitrophenyl as substrate, our results (Table 2) showed that EST-4 of D. mulleri had higher affinity for the substrate than $D$. arizonae. The $K_{\mathrm{m}}$ of EST-4 was much lower in the first species $(0.17 \mathrm{mM})$ than in the second $(0.74 \mathrm{mM})$, revealing that the concentration of $\rho$-nitrophenyl acetate needed for the enzyme to reach half of its maximum speed in $D$. mulleri is more than four times lower than that in D. arizonae. However, although the EST-4 affinity for this substrate in D. mulleri was much higher, its maximum velocity was approximately 20 times lower than in $D$. arizonae $\left(V_{\max }: D\right.$. mulleri $=0.94 \mathrm{mM}$ $\min ^{-1}, D$. arizonae $\left.=19.33 \mathrm{mM} \mathrm{min}{ }^{-1}\right)$, having higher catalytic efficiency over the $\rho$-nitrophenyl acetate substrate.

Regarding the number of reaction cycles performed per unit of time, $k_{\text {cat }}$, it was possible to infer that the
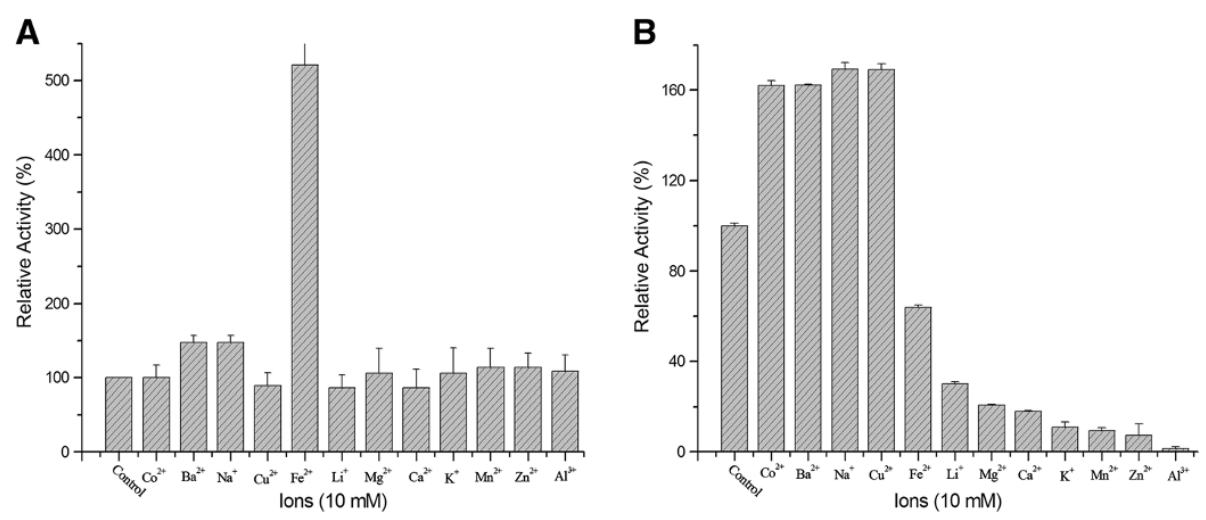

Figure 9 EST-4 activity in the presence of ions. (A) D. mulleri. (B) D. arizonae. 
Table 2 EST-4 kinetic parameters using p-nitrophenyl acetate as substrate

\begin{tabular}{lcccc}
\hline Species & $\boldsymbol{K}_{\mathrm{m}}(\mathrm{mM})$ & $\begin{array}{c}\boldsymbol{V}_{\text {max }} \\
\left(\mathbf{m M ~ m i n}^{-1}\right)\end{array}$ & $\begin{array}{c}\boldsymbol{k}_{\text {cat }} \\
\left(\mathbf{m i n}^{-1}\right)\end{array}$ & $\begin{array}{c}\boldsymbol{k}_{\text {cat }} / \boldsymbol{K}_{\mathbf{m}} \\
\left(\mathbf{m M}^{-1} \mathbf{m i n}^{-1}\right)\end{array}$ \\
\hline D. mulleri & 0.17 & 0.94 & 94.54 & 532.0 \\
D. arizonae & 0.74 & 19.33 & $1,933.00$ & $2,583.8$ \\
\hline
\end{tabular}

EST-4 of D. arizonae can convert the substrate into a product with higher efficiency $\left(1,933 \mathrm{~min}^{-1}\right)$ as compared to the EST-4 of D. mulleri $\left(94.54 \mathrm{~min}^{-1}\right)$. The catalytic efficiency $\left(k_{\text {cat }} / K_{\mathrm{m}}\right)$ corroborated these results as the EST-4 of $D$. arizonae showed higher catalytic efficiency $\left(2,583.8 \mathrm{mM}^{-1} \mathrm{~min}^{-1}\right)$ when compared to $D$. $\mathrm{mul}$ leri $\left(532 \mathrm{mM}^{-1} \mathrm{~min}^{-1}\right)$.

\section{Conclusions}

Our results clearly showed that these enzymes are very closely related and still maintain some similar features, such as optimal temperature and $\mathrm{pH}$. However, they already depict many other characteristics that show they have differentiated in the evolutionary time (effect of chemicals, $\mathrm{pH}$ stability, enzymatic affinity, $V_{\max }$, and catalytic efficiency). It seems that the EST-4 of D. arizonae is much better adjusted as an esterase enzyme than the EST-4 of D. mulleri because of its superior $K_{\text {cat }}$ and $K_{\text {cat }} / K_{\mathrm{m}}$. Considering that this enzyme of $D$. mulleri has more conspicuous difference in gel mobility among all EST-4 studied so far (Mateus et al. 2011) and its kinetic features observed here, it can be can propose that after duplication, one new copy of the original gene (in our case, the Est2c gene of EST-4) became redundant and started to decay toward a pseudogene status in this species, which probably is not occurring in $D$. arizonae. Balakirev and Ayala (1996) detected high frequencies of null alleles for the Est7 gene, which encodes the enzyme found in the integumental tissue of late larvae and early pupae in D. melanogaster. This seems like to be the possible explanation for the observations detected for the EST-4 of D. mulleri.

\section{Abbreviations \\ Abs: absorbance; BICINE: N,N-bis(2-hydroxyethyl)glycine; BSA: bovine serum albumin; CAPS: 3-(cyclohexylamino)-1-propanesulfonic acid; e: molar extinction coefficient of $\rho$-nitrophenyl; EDTA: ethylenediamine tetraacetic acid; HEPES: 4-(2-hydroxyethyl)piperazine-1-ethanesulfonic acid; IEC: ion exchange chromatography; JHE: juvenile hormone esterase; kDa: kilodalton; MES: 2-[N-morpholino]ethanesulfonic acid; MMEC: molecular mass exclusion chromatography; NaCl: sodium chloride; PAGE: polyacrylamide gel electrophoresis; PMSF: phenylmethanesulfonyl fluoride; SDS: Sodium dodecyl sulfate; $t$ : time in minutes; TAPS: $N$-[tris(hydroxymethyl)methyl]-3- aminopropanesulfonic acid; $V_{E}$ : volume of enzyme; $V_{R}$ : volume of reaction.}

\section{Competing interests}

The authors declare that they have no competing interests.

\section{Authors' contributions}

VFL carried out all the biochemical analyses and drafted the manuscript. $\mathrm{HC}$ participated in the design of the study and helped in the biochemical analyses and in drafting the manuscript. LPBM participated in the design of the study and helped in drafting the manuscript. RPM conceived of the study, and participated in its design and coordination, and helped in drafting the manuscript. All authors read and approved the final manuscript.

\section{Acknowledgements}

We are thankful to Prof. Dr. Carlos R. Ceron for providing the Drosophila strains, to Prof. Dr. Maura H. Manfrin for opening her laboratory to us in order to maintain and to perform the experiments with these strains to obtain all the samples for purification, and to Ronivaldo Rodrigues da Silva and Nathalia G. Rosa for technical assistance in the laboratory experiments. Funds were provided by the following: SETI/Fundação Araucária (V. F. Lopes Master's Fellowship), Fundação de Amparo à Pesquisa do Estado de São Paulo (FAPESP) (H. Cabral, grant number 2011/06986-0), Financiadora de Estudos e Projetos (FINEP), Coordenação de Aperfeiçoamento de Pessoal de Nível Superior (CAPES), Faculdade de Ciências Farmacêuticas de Ribeirão Preto da Universidade de São Paulo (FCFRP/USP), and Universidade Estadual do Centro-Oeste (UNICENTRO).

\section{Author details}

'Laboratório de Genética e Evolução, Departamento de Ciências Biológicas, Universidade Estadual do Centro-Oeste (UNICENTRO), Campus CEDETEG, R. Simeão Camargo Varela de Sá, 03-Vila Carli, Guarapuava, Paraná 85040-080, Brazil. ${ }^{2}$ Laboratório de Tecnologia Enzimática, Faculdade de Ciências Farmacêuticas de Ribeirão Preto, Universidade de São Paulo (USP), Av. do Café - s/n, Bairro Monte Alegre, Ribeirão, Preto, São Paulo 14040-903, Brazil.

Received: 28 September 2013 Accepted: 9 January 2014

Published: 24 January 2014

\section{References}

Anthony N, Rocheleau T, Mocelin G, Lee H-J, Ffrench-Constant R (1995) Cloning, sequencing and functional expression of an acetylcholinesterase gene from the yellow fever mosquito Aedes aegypti. FEBS Lett 368:461-465

Balakirev ES, Ayala FJ (1996) Is esterase-P encoded by a cryptic pseudogene in Drosophila melanogaster? Genetics 144:1511-1518

Balakirev ES, Ayala FJ (2003) Molecular population genetics of the beta-esterase gene cluster of Drosophila melanogaster. J Genet 82:115-131

Balakirev ES, Ayala FJ (2004) The beta-esterase gene cluster of Drosophila melanogaster: is psiEst6 a pseudogene, a functional gene, or both? Genetica 121:165-179

Balakirev ES, Chechetkin VR, Lobzin W, Ayala FJ (2003) DNA polymorphism in the $\beta$-Esterase gene cluster of Drosophila melanogaster. Genetics 164:533-544

Balakirev ES, Chechetkin VR, Lobzin W, Ayala FJ (2005) Entropy and GC content in the beta-esterase gene cluster of the Drosophila melanogaster subgroup. Mol Biol Evol 22:2063-2072

Balakirev ES, Anisimova M, Ayala FJ (2006) Positive and negative selection in the beta-esterase gene cluster of the Drosophila melanogaster subgroup. J Mol Evol 62:496-510

Bradford MM (1976) A rapid and sensitive method for the quantitation of microgram quantities of protein-dye binding. Anal Biochem 72:248-254

Brady JR, Richmond RC (1990) Molecular analysis of evolutionary changes in the expression of Drosophila esterases. Proc Natl Acad Sci U S A 87:8217-8221

Brady JR, Richmond RC (1992) An evolutionary model for the duplication and divergence of esterase genes in Drosophila. J Mol Evol 34:506-521

Campbell PM, Healy MJ, Oakeshott JG (1992) Characterisation of juvenile hormone esterase in Drosophila melanogaster. Insect Biochem Mol Biol 22:665-677

Campbell PM, Oakeshott JG, Healy MJ (1998) Purification and kinetic characterisation of juvenile hormone esterase from Drosophila melanogaster. Insect Biochem Mol Biol 28:501-515

Collet C, Nielsen KM, Russell RJ, Karl M, Oakeshott JG, Richmond RC (1990) Molecular analysis of duplicated esterase genes in Drosophila melanogaster. Molec Biol Evol 7:9-28

Coutinho-Abreu IV, Balbino VQ, Valenzuela JG, Sonoda IV, Ramalho-Ortigao JM (2007) Structural characterization of acetylcholinesterase 1 from the sand fly Lutzomyia longipalpis (Diptera: Psychodidae). J Med Entomol 44:639-650

Dumancic MM, Oakeshott JG, Russell RJ, Healy MJ (1997) Characterization of the EstP protein in Drosophila melanogaster and its conservation in drosophilids. Biochem Genet 35:251-271

Dunn BM (1989) Determination of protease mechanism. In: Beynon RJ, Bond JS (eds) Proteolytic enzymes: a practical approach. IRL, Oxford 
East RD, Graham A, Whitington G (1990) Molecular isolation and preliminary characterisation of a duplicated esterase locus in Drosophila buzzatii. In: Barker JSF, Starmer WT, Maclntyre RJ (eds) Ecological and evolutionary genetics of Drosophila. Plenum, New York

Gigliolli AAS, Lucena ALM, Lapenta AS (2011) Identificação e caracterização das esterases em Tribolium castaneum (Coleoptera: Tenebrionidae). SaBios Rev Saúde e Biol 6:25-35

Gomes GA, Hasson E (2003) Transpecific polymorphisms in an inversion linked esterase locus in Drosophila buzzatii. Mol Biol Evol 20:410-423

Harms MJ, Thornton JW (2013) Evolutionary biochemistry: revealing the historical and physical causes of protein properties. Nat Rev Genet 14:559-571

Hinton AC, Hammock BD (2003) In vitro expression and biochemical characterization of juvenile hormone esterase from Manduca sexta. Insect Biochem Mol Biol 33:317-329

Immanuel G, Esakkiraj P, Palavesam A (2010) Solid state production of esterase using groundnut oil cake by fish intestinal isolate Bacillus circulans. KKU Res J 15:459-474

Karotam J, Delves AC, Oakeshott JG (1993) Conservation and change in structural and $5^{\prime}$ flanking sequences of esterase 6 in sibling Drosophila species. Genetics 88:11-28

King LM (1998) The role of gene conversion in determining sequence variation and divergence in the Est5 gene family in Drosophila pseudoobscura. Genetics 148:305-315

Korochkin L, Ludwig M, Tamarina N, Uspensky I, Yenikolopov G, Khechumijan R, Kopantseva M, Evgeniev M, Kuzin B, Bakayeva T, Mudjoian L, Malevantschuk O, Tsatyian V, Ivanov A, Lukianov S (1990) Molecular genetic mechanisms of tissue specific esterase isozymes and protein expression in Drosophila. In: Markert C, Scandalios J (eds) Isozymes: structure, function and use in biology and medicine. Wiley-Liss, New York

Krejci E, Duval N, Chatonnet A, Vincens P, Massoulie J (1991) Cholinesterase-like domains in enzymes and structural proteins: functional and evolutionary relationships and identification of a catalytically essential aspartic acid. Proc Natl Acad Sci U S A 88:6647-6651

Laemmli UK (1970) Cleavage of structural proteins during the assembly of the head of bacteriophage T4. Nature 227:680-685

Lewis EB (1951) Pseudoallelism and gene evolution. Cold Spring Harb Symp Quant Biol 16:159-174

Li B, Wang YH, Liu HT, Xu YX, Wei ZG, Chen YH, Shen WD (2010) Genotyping of actylcholinesterase in insects. Pest Biochem Physiol 98:19-25

Lima-Catelani ARA, Ceron CR, Bicudo HEMC (2004) Variation of genetic expression during development, revealed by esterase patterns in Aedes aegypti (Diptera, Culicidae). Biochem Genet 42:69-84

Mateus RP, Cabral H, Bonilla-Rodriguez GO, Ceron CR (2009) Molecular weight estimation of esterase isoenzymes in closely related Drosophila species (Diptera: Drosophilidae) in non-denaturing polyacylamide gel electrophoresis. Braz Arch Biol Technol 52:1083-1089

Mateus RP, Machado LPB, Ceron CR (2011) Gene duplication and subsequent differentiation of esterases in cactophilic Drosophila species. In: Friedberg F (ed) Gene duplication, Book 2. InTech, Rijeka

Meikle DB, Sheehan KB, Phyllis DM, Richmond RC (1990) Localization and longevity of seminal-fluid esterase-6 in mated female Drosophila melanogaster. J Insect Physiol 36:93-101

Merheb-Dini C, Cabral H, Leite SR, Zanphorlin LM, Okamoto BN, Bonilla-Rodriguez GO, Arantes EC, Gomes E, Silva R (2009) Biochemical and functional characterization of a metalloprotease from the thermophilic fungus Thermoascus aurantiacus. J Agric Food Chem 57:9210-9217

Narise S, Hubby JL (1966) Purification of esterase-5 from Drosophila pseudoobscura. Biochim Biophis Acta 122:281-288

Oakeshott JG, Healy MJ, Game AY (1990) Regulatory evolution of $\beta$-carboxyl esterases in Drosophila. In: Barker JSF, Starmer WT, Maclntyre RJ (eds) Ecological and evolutionary genetics of Drosophila. Plenum, New York

Oakeshott JG, Van Papenrecht EA, Boyce TM, Healy MJ, Russel RJ (1993) Evolutionary genetics of Drosophila esterases. Genetics 90:239-268

Oakeshott JG, Boyce TM, Russell RJ, Healy MJ (1995) Molecular insights into an enzyme: esterase 6 in Drosophila. Trends Ecol Evol 10:103-110

Oakeshott JG, Claudianos C, Russell RJ, Robin GC (1999) Carboxyl/cholinesterases: a case study of the evolution of a successful multigene family. Bioessays 21:1031-1042
Oakeshott JG, van Papenrecht EA, Claudianos C, Morrish BC, Coppin C, Odgers WA (2000) An episode of accelerated amino acid change in Drosophila esterase- 6 associated with a change in physiological function. Genetica 110:231-244

Ohno S (1970) Evolution by gene duplication. Springer, Berlin

Pen J, Herman AHR, Beintema JJ (1984) Purification and properties of esterase-4 from Drosophila mojavensis. Biochim Biophis Acta 789:203-209

Pen J, Schipper A, Herman AHR, Beintema JJ (1986a) Differences in specificity and catalytic efficiency between allozymes of esterase-4 from Drosophila mojavensis. Mol Biol Evol 3:366-373

Pen J, Beeumen JV, Beintema JJ (1986b) Structural comparison of two esterases from Drosophila mojavensis isolated by immunoaffinity chromatography. Biochem J 278:691-699

Pen J, Bolks GJ, Hoeksema-Du P, Beintema JJ (1990) Serine esterases: structural conservation during animal evolution and a variability in enzymic properties in the genus Drosophila. Genetics 81:125-131

Richmond RC, Nielsen KM, Brady JE, Snella EM (1990) Physiology, biochemistry and molecular biology of the Est6 locus in Drosophila melanogaster. In: Barker JSF, Starmer WT, Maclntyre RJ (eds) Ecological and evolutionary genetics of Drosophila. Plenum, New York

Robin C, Bardsley LMJ, Coppin C, Oakeshott JG (2009) Birth and death of genes and functions in the $\beta$-esterase cluster of Drosophila. J Mol Evol 69:10-21

Saad M, Game AY, Healy MJ, Oakeshott JG (1994) Associations of esterase 6 allozyme and activity variation with reproductive fitness in Drosophila melanogaster. Genetica 94:43-56

See YS, Jackowski G (1989) Estimating molecular weights of polypeptides by SDS gel electrophoresis. In: Creigton TE (ed) Protein structure: a practical approach. Oxford University Press, Oxford

Semionato S (2006) Avaliação da atividade lipolítica de bactérias isoladas dos dispositivos de remoção de gordura da UTE-UFES. Dissertation, Universidade Federal do Espírito Santo

Silva RR (2011) Fermentação, purificação e caracterização da protease produzida por Aspergillus Fumigatus Fresenius. Dissertation, Universidade Estadual Paulista

Tamarina NA, Ludwig MZ, Richmond RC (1997) Divergent and conserved features in the spatial expression of the Drosophila pseudoobscura esterase-5B gene and the esterase- 6 gene of Drosophila melanogaster. Proc Natl Acad Sci USA 94:7735-7741

Thomazine VB (2007) Adaptabilidade diferencial das variantes moleculares "slow" e "fast" da esterase-5 de Drosophila mulleri. Dissertation, Universidade Estadual Paulista

Yu QY, Lu C, Li WL, Xiang ZH, Zhang Z (2009) Annotation and expression of carboxylesterases in the silkworm, Bombyx mori. BMC Genomics 10:553-566

Zera AJ, Sanger T, Hanes J, Harshman L (2002) Purification and characterization of hemolymph juvenile hormone esterase from the cricket, Gryllus assimilis. Arch Insect Biochem Physiol 49:41-55

Zhou GW, Guo J, Huang W, Fletterick J, Scanlan TS (1994) Crystal structure of a catalytic antibody with a serino protease active site. Science 265:1059-1064

Zouros E, van Delden W (1982) Substrate preference polymorphism at an esterase locus of Drosophila mojavensis. Genetics 100:307-314

Zouros E, van Delden W, Odense R, Dijk HV (1982) An esterase duplication in Drosophila: differences in expression of duplicate loci within and among related species. Biochem Genet 20:929-942

\section{doi:10.1186/1810-522X-53-6}

Cite this article as: Lopes et al.: Purification and characterization of a specific late-larval esterase from two species of the Drosophila repleta group: contributions to understand its evolution. Zoological Studies 2014 53:6. 